\title{
ON SEAMS AND SEAMLESSNESS
}

\author{
by
}

Rebecca Alpert

\begin{abstract}
Rebecca Alpert, Assistant Professor of Women's Studies at Temple University, has written extensively on contemporary Jewish themes. Her publications include Exploring Judaism: A Reconstructionist Approach and a forthcoming study of lesbian issues in Judaism.
\end{abstract}

When Laura Levitt, my friend and colleague at Temple University, asked me to participate in this forum, my first response was a categorical no. Laura and I bave talked about our different perspectives about postmodern approaches to Jewish feminism infrequently over the last several years. The conversations always end with us restating our differences, agreeing to disagree. Because my feelings are so strong about this subject, I was reluctant to bave this conversation in public. Yet Laura persuaded me to consider participation, in full knowledge that this would be an airing of our differences, and I bave taken the risk to do so. My contribution, a letter to Laura, is an effort to bring my love for ber into the context of what is, for me, a passionate and acrimonious intellectual debate that bas important implications for the future of Jewish feminism.

January 1995

\section{Dear Laura,}

I have read and re-read your questions and Miriam's essay many times now, looking for a way to engage in honest conversation. It is not an easy task. I have strong and positive feelings about our relationship and admire the work you have done. But these questions and this essay perplex me deeply. I fear we do not speak the same language and as a result efforts at communication may not be fruitful. Yet I am compelled to respond to you, to articulate for you what I don't understand, what I think is not unique about this work, what I disagree with, and where our visions part. 
I don't understand why you get so passionate about categories, definitions, and terms. Really, aren't there greater and more significant conflicts than those about what specific words mean? When you argue over words you run the risk of engaging in debates about words only. How I translate my beliefs into action is more salient than the words I use to describe my actions and beliefs.

The words you use get in the way of my understanding as well. Why must you invent words like tropes and signifiers? Do you really expect people outside of the academy to benefit from your work when they can't understand what you're talking about? The beauty of the feminist enterprise has been its ability to make connections between activists and academicians, and of the Jewish feminist enterprise to enable those who practice Judaism in whatever way to have access to Jewish feminist ideas that emanate from the academy. However do we justify speaking in a language that is at best self-referential and at worst elitist and alienating to those we want to connect to?

The other thing I don't understand is why you are so deeply disturbed about the Enlightenment. I believe as I'm sure you do that the Enlightenment served a useful purpose, opening up new ways of thinking about the world and about God. Without this perspective we could not be asking the questions we ask today. Yet you invariably look at the Enlightenment as the embodiment of all you disdain. I'm often troubled by how you repeat what you consider to be the Enlightenment's mistake of creating "binaries" by turning enlightenment consciousness into the "other" against which you react. I just don't understand your need to do this.

While I appreciate some of your insights, I don't see what is so unique about them. Hasn't feminism for years contended that knowledge is partial, and that what is wrong with traditional approaches is that they universalize man? And didn't feminists come years ago to the realization that universalizing women was also problematic? Acceptance of difference among us is an important feature of Jewish feminism, as we have struggled for years to accept one another's differences in religious perspectives, political orientation, sexuality, cultural background, class, and so on.

We certainly agree that you cannot "add women and stir" to bring questions about gender into the conversation. Miriam acknowledges this as a truism. Her solution of teaching Seltzer and Baskin side by side, and teaching historiography as well as history, is a useful strategy, but she is not unique in her approach. Others have been finding ways to make gender a crucial factor in the teaching of Jewish history and other subjects for quite some time. 
It is also not a new insight that students of Jewish history have glossed over the subversive and radical elements in the Jewish past, in the effort to make Judaism appear to be seamless. The feminist project of looking at the past means always searching out what is hidden. Miriam's analogy about the construction site is a good one. I would be surprised if any feminist scholar disagreed.

But there is also much in what you say with which I do disagree. Understanding complexity, looking at the building blocks, is crucial to the production of knowledge. But messiness is not a virtue, it is merely a part of the process of rebuilding. My profound disagreement with your perspective is that you seem to think you're finished with a project when you have exposed all the wiring. What is important is to expose the structure and then to rebuild the building, retaining always the awareness of what it looked like inside. Living with the contradiction that a seemingly seamless garment is in fact made up of seams is what the goal should be.

I was also deeply troubled by Miriam's approach to the midrashic method of inquiry. In the first place, midrash is much less a product of modernity than is the historical method of Jewish scholarship. It was the maskilim who were the first to value historical research. The first postbiblical histories of the Jews other than the one written by Josephus were produced by wissenschaft scholars. Midrash, on the other hand, has received scant attention in non-feminist modern Jewish thought. The work of Yerushalmi that so disturbs Miriam was not a move to discount history, but to render another dimension to the historical enterprise.

Miriam contends that history is more accessible than midrash, "distributed orally throughout various levels and types of schools." But she is wrong about this. History is much less accessible and widely distributed than is the telling of stories. Hanukkah is the perfect example. To the person who knows little of Judaism, Hanukkah does not commemorate an historical event. It is more likely to be understood as the "miracle of the oil." Because of its hold on the popular imagination, midrash is a much more effective means of making the feminist project accessible to many people.

But accessibility doesn't seem to be a goal. Miriam disagrees with the idea that feminism should be providing the opportunity for all women to speak. Aware of the problem that not all women speak as feminists, she abandons the commitment to providing opportunities for women's voices to be heard. This is the most objectionable dimension of her analysis. Surely feminists want to give women an opportunity to say what we are thinking, even if we disagree, and even if much of what we say is bound up in a masculinist perspective. How else can we create change if not by 
our commitment to providing opportunities for everyone to have their voices heard, for dialogue to exist?

Midrash succeeds at presenting an alternative to historical research, and to the real "dominant discourse" in Judaism, halakhah. The creation of feminist midrash has been an amazing process of recreating our people's history and questioning Jewish "norms." Jewish life is based much more on a collective memory and perception, on stories of how we came to be, than Miriam acknowledges. In Jewish communities all across North America, Jewish feminists have made women part of the Jewish landscape by telling stories about Sarah's role in the binding of Isaac, making Miriam comparable to Moses as a leader of the Jewish people, recognizing Vashti as a possible role model alongside Esther, and reexamining the significance of Ruth as ancestor to converts and paradigm of passionate friendship between women. These stories have done more to shape a feminist consciousness than a hundred archaeological digs. This is true because these stories rely on imaginative reconstruction. They can be written by anyone, of any age, including children. Again, accessibility is a crucial component for creating change.

My final problem with your approach is that I don't see how you expect to bring about your vision for Jewish feminism. Miriam says that your goal is to make the "marginalization of women and gender intellectually impossible." The goal sounds right, but how you will get there isn't clear. Miriam suggests at the end of her essay that her linguistic moves don't change things very much; an engendered Judaism still retains the separation of the categories gender and Judaism. She doesn't have an answer to her own question about what critical tools are really necessary to explain how genders are engendered.

But I wonder if those are the right questions. What does this perspective add that isn't already being questioned in progressive and feminist Jewish circles beyond inaccessible language and hypercritical arguments? An exciting vision for Jewish feminism is to continue to cast a critical eye and at the same time to create events and images that will and have made Judaism look different. We must learn to live with the contradictions of what will inevitably be an imperfect enterprise.

We must also be sure that we do not make gender the only category we ask questions about in Jewish contexts. Our differences are about geography and age, sexuality and race, physical ability and religious preferences. And they are also about approaches-Orthodox, Zionist, Secular, Reconstructionist, Post-modern, Feminist, Progressive, and any combination of these and others. We need to learn to live with the 
contradiction that we can both disagree and live in harmony, and that there is room in the Jewish world for us all.

So I write in the spirit of dialogue and in the hope that the angry and hurt tones these conversations across generations have begun to take do not keep us from seeing the vision we share of living and changing Judaism. Those of us who have been engaged in this effort for a long time feel frustrated when we look around and see that not as much has changed in the Jewish community as we would have liked, given our efforts and struggles. And we also feel anger when our work is judged harshly by those in the next generation of Jewish feminists, whom we hoped would find within our work the blueprint to continue the process of change. The only solution to the problem is to keep talking and working in concert. While I began this effort feeling uncomfortable arguing with you in public, I end the process seeing the advantage of keeping the channels of communication open.

In hope that this discussion can continue in peace and friendship,

Rebecca 